\title{
Usporedba znanja hrvatskih i slovenskih osnovnoškolaca te gimnazijalaca o evoluciji čovjeka
}

\author{
Lara Kralj, Tanja Šalamon, Žaklin Lukša \\ Gimnazija Josipa Slavenskog Čakovec, V, Nazora 34, Čakovec \\ lara.kralj1993@gmail.com
}

\section{SAŽETAK}

Prethodna istraživanja pokazuju da učenici imaju teškoće u razumijevanju evolucije čovjeka zbog zahtjevnosti teme. Cilj rada je bio utvrditi kakvo je znanje hrvatskih i slovenskih osnovnoškolaca te gimnazijalaca o evoluciji čovjeka. Nastojalo se utvrditi postoji li razlika u znanju učenika između dviju država, spolova, vrste škola te dobi učenika. Osim znanja, željelo se utvrditi i postojanje učeničkih miskoncepcija o evoluciji čovjeka. Istraživanje je provedeno 2017. godine u slovenskim i hrvatskim gimnazijama te osnovnim školama. Sudjelovalo je 170 učenika, od čega 100 osnovnoškolaca, te 70 gimnazijalaca iz obiju zemalja. Ukupni prosječni uspjeh na ispitu znanja bio je 64,8 \%. Najzastupljeniji točan odgovor učenika odnosio se na nalazište neandertalaca u Hrvatskoj, kod kojeg je $96,4 \%$ učenika odabralo Krapinu kao točan odgovor. Rezultati su pokazali da postoje razlike u znanju o evoluciji čovjeka između učenika različitih zemalja, škola i razreda. Slovenski gimnazijalci su pokazali više znanja o evoluciji čovjeka u odnosu na hrvatske (14 statistički značajnih razlika; $p<0,05)$, dok su hrvatski osnovnoškolci bili uspješniji od slovenskih (16 statističko značajnih razlika; $p<0,05$ ). Hrvatski gimnazijalci pokazali su lošije rezultate na ispitu od slovenskih osnovnoškolaca. Osnovnoškolsko znanje o evoluciji čovjeka se razlikuje od gimnazijskog po učestalosti točnih odgovora. Hrvatski osnovnoškolci su pokazali više znanja o evoluciji čovjeka od hrvatskih gimnazijalaca. Postoje razlike u poznavanju evolucije čovjeka među spolovima, ali nisu statistički značajne. I hrvatski i slovenski učenici imaju slične miskoncepcije povezane s evolucijom čovjeka. Čak $41,5 \%$ učenika smatra da su se ljudi razvili iz čimpanzi, a da smo potomci biblijskog Adama i Eve smatra $39,2 \%$ učenika. Dobiveni rezultati trebali bi utjecati na promjene u poučavanju sa svrhom postizanja boljih rezultata učenika vezanih uz koncept evolucije čovjeka, a posebice na sprečavanje stvaranja uočenih miskoncepcija.

Ključne riječi: evolucija čovjeka; znanje; Hrvatska; Slovenija; osnovna škola; gimnazija

\section{UVOD}

Dosadašnja istraživanja ukazuju da su u učeničkom razumijevanju koncepta evolucije čovjeka postoje određene miskoncepcije. Evolucija je važan znanstveni koncept (Ridley, 2004) te se smatra da je razumijevanje evolucije jedna od važnijih sastavnica prirodoznanstvene pismenosti učenika (Bybee, 2004). Istodobno je to izazovna tema koju učenici teško razumiju. Uzrok tome su različiti emocionalni, epistemološki te vjerski čimbenici koji doprinose pogledu na svijet koji nije evolucijski (Nehm i sur, 2007; Smith, 2010). lako je sadržaj biologije jasno prikazan u nastavnom planu i programu, ni u hrvatskim ni u slovenskim nastavnim programima nije predviđen zadovoljavajući broj sati niti jasno definirani ciljevi koji bi pridonijeli razumijevanju evolucije čovjeka. Slovenski gimnazijski nastavni plan i program iz biologije predviđa 25 sati evolucije sa samo jednim ishodom koji se odnosi na ljudski razvoj. Taj ishod glasi: „Učenici upoznaju glavne prekretnice u evoluciji ljudske vrste (Australopithecus afarensis, Homo erectus, Homo sapiens, širenje iz Afrike)“ (Vičar i sur., 2008). Slovenski osnovnoškolski plan i program sadrži isto tako jedan ishod vezan uz evoluciju čovjeka, a to je: „Učenici znaju objasniti izvor primata i ljudi te povezanost čovjeka s drugim primatima“ (Vilhar i sur., 2011). Taj jedini ishod u nastavnom planu i programu nije dovoljan da bi učenici razumjeli ljudski 
razvoj (Bajd, 2012). Hrvatski osnovnoškolski nastavni plan i program iz biologije se u tom smislu ne razlikuje značajno od slovenskog. Sadrži samo jedan ishod, povezan s razumijevanjem evolucije čovjeka. On glasi: „Učenici pronalaze sličnosti između modernog čovjeka i izumrlih čovjekolikih majmuna, odrede osobine modernog čovjeka koje ga odvajaju od čovjekolikih majmuna te saznaju više o nalazištu neandertalaca u Hrvatskoj" (Vican i sur., 2006). U Hrvatskom nastavnom programu za gimnazije je situacija još lošija. Hrvatska ima važeći nastavni plan i program za biologiju iz 1995. godine, koji se do danas nije mijenjao. Evolucija čovjeka je ograničena jednim navodom koji zahtijeva da učenici uče o razvoju i raznolikosti živog svijeta, teoriju evolucije, živi svijet kroz prošlost te specijaciju čovjeka (Ministarstvo prosvjete i športa, 1995).

Pristup podučavanju koncepta evolucije čovjeka trebao bi biti objektivan, a osobni stav nastavnika prema religiji ne bi smio utjecati na učenike (Smith, 2010). Na prihvaćanje ljudskog podrijetla utječe spol, starost, stupanj obrazovanja, socioekonomski status, geografsko područje života, vrsta religije i samo razumijevanje makroevolucije (Barnes, 2014). Pojedini učenici imaju negativan stav prema konceptu evolucije jer se protivi njihovoj vjeri te zbog prisutnog rasizma (Pobiner, 2016). Vjerska uvjerenja su u suprotnosti sa znanstvenim konceptom razvoja čovjeka. Kreacionistička ideja o nastanku svijeta predstavlja Boga kao stvoritelja ljudi (Mpeta, 2013), dok evolucionisti podržavaju skup činjenica utemeljenih na znanstvenoj teoriji te vjeruju da u nastavi nema prostora za "alternativno" objašnjavanje podrijetla ljudi (Smith, 2010), budući da se vjerska teorija ne temelji na empirijskim dokazima i činjenicama. Iz tog razloga dolazi do sukoba između učenika koji nisu istog stajališta o evoluciji čovjeka. Vrsni autori vjeruju da nastavnicima trebamo omogućiti bolje alate u podučavanju ljudskog razvoja te u tu svrhu predlažu različite metode rada (Flammer, 2003; Pobiner, 2012; Price, 2012). Alles i Stevenson (2003) tvrde da će u razumijevanju koncepta evolucije čovjeka doprinijeti temeljni okvir spoznaja o evoluciji čovjeka, umjesto detaljnih popisa imena te evolucijskih znanstvenika. Pobiner (2016) tvrdi da miskoncepcije uključenje u evoluciju čovjeka uvelike utječu na prihvaćanje koncepta evolucije. Nastale su zbog vjerskih, filozofskih i socijalnih čimbenika. Najčešće miskoncepcije učenika su da je Bog stvorio svaku vrstu posebno (Farber, 2003), da su neandertalci živjeli na drveću kao majmuni ili u špiljama (Bajd, 2010; Povšić, 2012) te da su živjeli za vrijeme dinosaura (Bajd i sur., 2009). Među općenitim miskoncepcijama uvrštena je i najizloženija, naime, učenici smatraju da su se ljudi razvili iz čimpanzi. Pretpostavljaju da su majmuni izgubili kosu i rep tijekom evolucije (Pobiner, 2016).

Cilj istraživanja bio je utvrditi je li poznavanje evolucijskog razvoja Homo sapiensa na kraju osnovnoškolskog obrazovanja zadovoljavajuće te koliko se ono razlikuje od znanja gimnazijalaca. Također se željelo utvrditi i postoje li razlike u postignućima između hrvatskih i slovenskih učenika uz prepoznavanje potencijalnih miskoncepcija u poznavanju evolucije čovjeka.

\section{METODE}

Za istraživanje se koristio anoniman ispit znanja o evoluciji čovjeka (u prilogu). Ispit znanja se provodio 2017. godine u različitim školama na satovima biologije. Testirano je 170 učenika, od toga 100 hrvatskih i 70 slovenskih. Istraživanje se provelo u 4 različite škole. U Osnovnoj školi Sveti Martin na Muri testirano je 50 učenika, kao i u Sloveniji u Osnovnoj školi Valentin Vodnika u Ljubljani. Anoniman ispit znanja riješilo je isto tako 50 gimnazijalaca Gimnazije Josipa Slavenskog Čakovec, preostalih 20 učenika testirano je u Gimnaziji Vič u Ljubljani. Većina testiranih učenika bila je muškog spola (61,2 \%), a populaciju ženskog spola činilo je $37,1 \%$ učenika. 
Anoniman ispit znanja o evoluciji čovjeka sastavljen je od tri dijela. Prvi dio je namijenjen osnovnim demografskim podacima, kao što su dob i spol. U drugom dijelu su učenici odgovarali na pitanja otvorenog tipa o evoluciji čovjeka. Pored njih bila je deset-stupanjska ljestvica, na kojoj su učenici označili koliko su sigurni u svoj odgovor. Broj 0 na ljestvici značio je nagađanje, a 10 da je učenik znao odgovor na pitanje. Na preostalih 28 pitanja učenici su na Likertovoj ljestvici s četiri razine (od 1 do 4) trebali označiti koliko se slažu ili ne slažu s određenom tvrdnjom o ljudskom podrijetlu. Pritom je broj 1 označavao da se nikako ne slažu s tvrdnjom, a broj 4 da se veoma slažu. Za analizu istraživanja koristio se SPSS program, te su se podaci s Mann-Whitney testom statistički obradili. Nakon analize podataka odabrani su odgovori učenika koji sadrže određene miskoncepcije o evoluciji čovjeka te odgovori koji su važni za propisani plan i program biologije u Hrvatskoj i Sloveniji.

\section{REZULTATI}

Tablica 1 prikazuje srednje vrijednosti i standardne devijacije za sva ispitna pitanja koja su analizirana pomoću SPSS programa. Ukupno postignuće učenika na anonimnom ispitu o evoluciji čovjeka bilo je svega $64,8 \%$ ukupne uspješnosti (tablica 2 ).

Tablica 1 Prikaz srednje vrijednosti i standardne devijacije za sva ispitna pitanja

\begin{tabular}{|c|c|c|c|c|c|}
\hline $\begin{array}{c}\text { Redni broj } \\
\text { pitanja / } \\
\text { tvrdnje }\end{array}$ & $\begin{array}{c}\text { Srednja } \\
\text { vrijednost }\end{array}$ & $\begin{array}{c}\text { Standardna } \\
\text { devijacija }\end{array}$ & $\begin{array}{c}\text { Redni broj } \\
\text { pitanja / } \\
\text { tvrdnje }\end{array}$ & $\begin{array}{l}\text { Srednja } \\
\text { vrijednost }\end{array}$ & $\begin{array}{c}\text { Standardna } \\
\text { devijacija }\end{array}$ \\
\hline 1. & 8,73 & 1,976 & 18. & 3,43 & 0,735 \\
\hline 2. & 5,77 & 3,629 & 19. & 2,64 & 1,064 \\
\hline 3. & 5,84 & 2,924 & 20. & 1,39 & 0,700 \\
\hline 4. & 6,25 & 2,906 & 21. & 2,27 & 1,095 \\
\hline 5. & 5,69 & 2,841 & 22. & 3,60 & 0,830 \\
\hline 6. & 8,76 & 2,785 & 23. & 2,20 & 1,168 \\
\hline 7. & 2,65 & 1,079 & 24. & 2,48 & 0,777 \\
\hline 8. & 3,35 & 0,740 & 25. & 2,20 & 0,901 \\
\hline 9. & 3,08 & 0,947 & 26. & 2,40 & 1,136 \\
\hline 10. & 3,56 & 0,815 & 27. & 2,44 & 0,865 \\
\hline 11. & 3,64 & 0,682 & 28. & 2,67 & 0,960 \\
\hline 12. & 2,10 & 1,054 & 29. & 2,56 & 0,922 \\
\hline 13. & 2,32 & 0,997 & 30. & 1,87 & 0,900 \\
\hline 14. & 2,38 & 1,012 & 31. & 1,91 & 0,922 \\
\hline 15. & 3,20 & 0,780 & 32. & 3,45 & 0,776 \\
\hline 16. & 3,41 & 0,820 & 33. & 3,26 & 0,850 \\
\hline 17. & 2,83 & 0,833 & 34. & 3,35 & 0,808 \\
\hline
\end{tabular}

Tablica 2 Postotak točnih odgovora svih testiranih učenika na određeno pitanje

\begin{tabular}{|c|c|c|c|c|c|}
\hline $\begin{array}{l}\text { Redni } \\
\text { broj } \\
\text { pitanja }\end{array}$ & $\begin{array}{c}\text { Točni } \\
\text { odgovori (\%) }\end{array}$ & $\begin{array}{c}\text { Redni } \\
\text { broj } \\
\text { pitanja }\end{array}$ & $\begin{array}{c}\text { Točni } \\
\text { odgovori } \\
\text { (\%) }\end{array}$ & $\begin{array}{c}\text { Redni } \\
\text { broj } \\
\text { pitanja }\end{array}$ & $\begin{array}{c}\text { Točni } \\
\text { odgovori } \\
\text { (\%) }\end{array}$ \\
\hline 1. & 69,4 & 12. & 58,5 & 23. & 60,9 \\
\hline 2. & 45,6 & 13. & 42,8 & 24. & 51,3 \\
\hline 3. & 46,7 & 14. & 46,9 & 25. & 62,2 \\
\hline 4. & 47,9 & 15. & 83,8 & 26. & 52,2 \\
\hline 5. & $1,2(a+d+e)$ & 16. & 87,2 & 27. & 50,9 \\
\hline 6. & 96,4 & 17. & 69,4 & 28. & 62,3 \\
\hline 7. & 58,9 & 18. & 91,5 & 29. & 56,3 \\
\hline 8. & 91,2 & 19. & 44,8 & 30. & 76,0 \\
\hline 9. & 72,3 & 20. & 92,2 & 31. & 74,2 \\
\hline 10. & 87,8 & 21. & 42,0 & 32. & 87,3 \\
\hline 11. & 94,6 & 22. & 89,8 & $\Sigma$ & 64,8 \\
\hline
\end{tabular}


Za analizu istraživanja odabrala su se najznačajnija pitanja, tvrdnje i odgovore učenika. Rezultati su prikazani pomoću grafova (slika 1 i slika 2). Najbolji i najlošiji odgovori učenika pokazali su se na različitim pitanjima vezanim uz evoluciju čovjeka i kreacionizam.

Tablica 3 prikazuje 14 statistički značajnih razlika između hrvatskih i slovenskih gimnazijalaca ${ }^{*} \mathrm{p}<$ $0,05)$. Slovenski gimnazijalci su pokazali više znanja o evoluciji čovjeka u odnosu na hrvatske. Tablica 4 prikazuje 16 statistički značajnih razlika između hrvatskih i slovenskih osnovnoškolaca ( $\left.{ }^{*} p<0,05\right)$. Hrvatski osnovnoškolci su pokazali više znanja o evoluciji čovjeka u odnosu na slovenske.

\begin{tabular}{|c|c|c|c|}
\hline $\begin{array}{l}\text { Redni } \\
\text { broj } \\
\text { pitanja }\end{array}$ & $\begin{array}{l}\text { Mann- } \\
\text { Whitney } \\
\text { test } \\
\text { (p) }\end{array}$ & $\begin{array}{c}\text { Redni } \\
\text { broj } \\
\text { pitanja }\end{array}$ & $\begin{array}{c}\text { Mann- } \\
\text { Whitney test } \\
\text { (p) }\end{array}$ \\
\hline 2. & $0,000 *$ & 20. & $0,012^{*}$ \\
\hline 4. & $0,001^{*}$ & 22. & $0,042 *$ \\
\hline 5. & $0,029 *$ & 23. & $0,013^{*}$ \\
\hline 13. & $0,046^{*}$ & 25. & $0,002^{*}$ \\
\hline 14. & $0,000^{*}$ & 26. & $0,000 *$ \\
\hline 16. & $0,037^{*}$ & 29. & $0,009 *$ \\
\hline 19. & $0,001^{*}$ & 30. & $0,003^{*}$ \\
\hline
\end{tabular}

\begin{tabular}{|c|c|c|c|}
\hline $\begin{array}{c}\text { Redni } \\
\text { broj } \\
\text { pitanja }\end{array}$ & $\begin{array}{l}\text { Mann- } \\
\text { Whitney } \\
\text { test } \\
\text { (p) }\end{array}$ & $\begin{array}{c}\text { Redni broj } \\
\text { pitanja }\end{array}$ & $\begin{array}{l}\text { Mann- } \\
\text { Whitney } \\
\text { test } \\
\text { (p) }\end{array}$ \\
\hline 1. & $0,000^{*}$ & 14. & $0,003^{*}$ \\
\hline 2. & $0,036^{*}$ & 17. & $0,006^{*}$ \\
\hline 3. & $0,000^{*}$ & 19. & $0,007^{*}$ \\
\hline 4. & $0,000^{*}$ & 21. & $0,036^{*}$ \\
\hline 5. & $0,014^{*}$ & 24. & $0,004^{*}$ \\
\hline 7. & $0,028^{*}$ & 26. & $0,000^{*}$ \\
\hline 11. & $0,020^{*}$ & 28. & $0,007^{*}$ \\
\hline 13. & $0,002^{*}$ & 29. & $0,013^{*}$ \\
\hline
\end{tabular}

Slika 1 prikazuje najuspješnije odgovore učenika. Točni odgovori na grafu su obojani zelenom, a netočni crvenom bojom. Najveći postotak učenika znao je gdje se nalazi nalazište neandertalaca u Hrvatskoj. Svega 96,4\% učenika odabralo je odgovor Krapina. S tvrdnjom, da fosili pokazuju kako su se oblici života mijenjali kroz prošlost, slagalo se 94,6 \% učenika. Velikoj većini učenika je također jasno da se moderan čovjek razvio procesom evolucije (91,5\%).
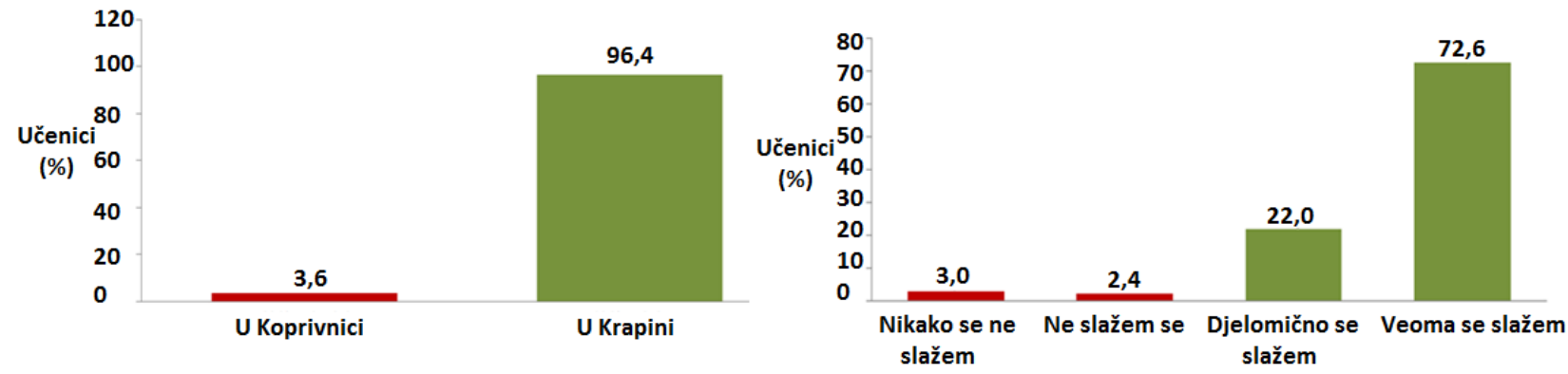

Gdje se nalazi nalazište neandertalaca u Hrvatskoj?

Fosili pokazuju kako su se oblici života mijenjali kroz prošlost.

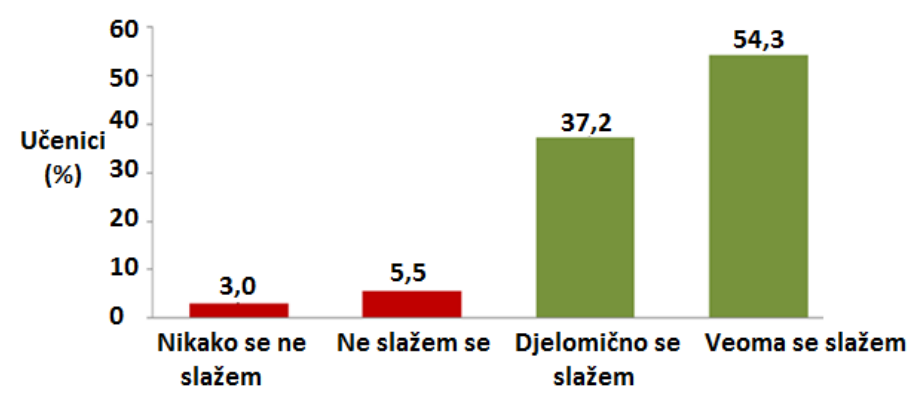

Moderan čovjek je nastao procesom evolucije.

Slika 1 Najuspješniji odgovori učenika o evoluciji čovjeka 
Na slici 2 su prikazani postotci točnih i netočnih tvrdnja o razvoju čovjeka. Učenici su mišljenja da su se ljudi razvili iz majmuna - čimpanzi. S tom netočnom tvrdnjom slaže se čak $41,5 \%$ ispitanih učenika. Podijeljena mišljenja su isto tako u vezi biblijskog Adama i Eve, gdje ih $39,2 \%$ misli da su svi ljudi njihovi potomci. $24 \%$ učenika smatra da biblija najbolje objašnjava kako se na Zemlji razvio čovjek. Otprilike polovica ispitanih učenika vjeruje da se moderan čovjek razvio iz neandertalca $(55,2 \%)$. Uz sve te kreacionističke teorije, učenici nisu pokazali ni biološko znanje. Svega $57,2 \%$ učenika smatra da ljudi nemaju više od polovice gena jednakih kao i miševi.

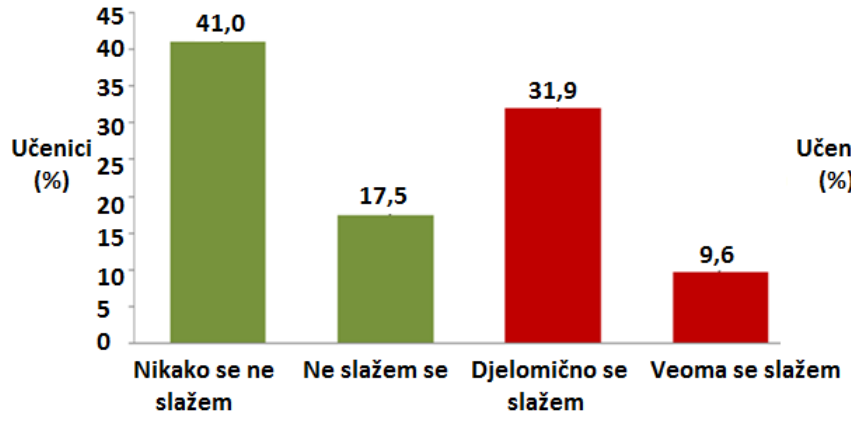

Ljudi su se razvili iz čimpanzi.

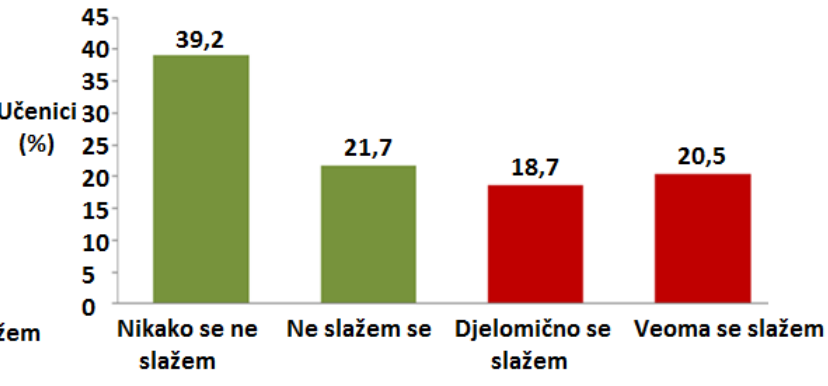

Svi ljudi su potomci jednog muškarca i jedne žene - biblijskog Adama i Eve.

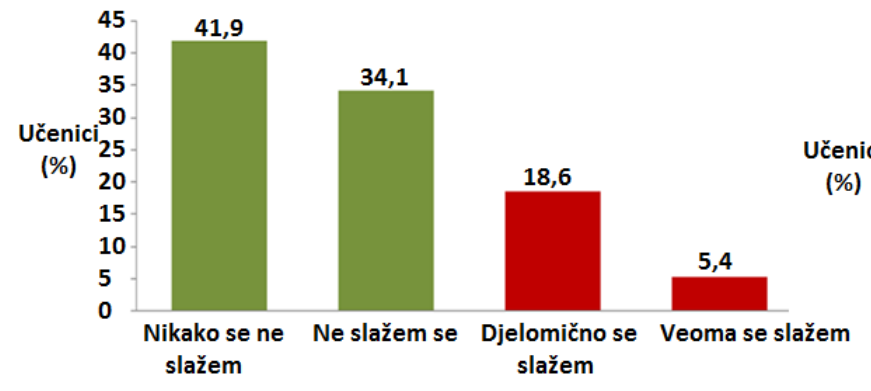

Biblija najbolje objašnjava kako se na Zemlji razvio čovjek.

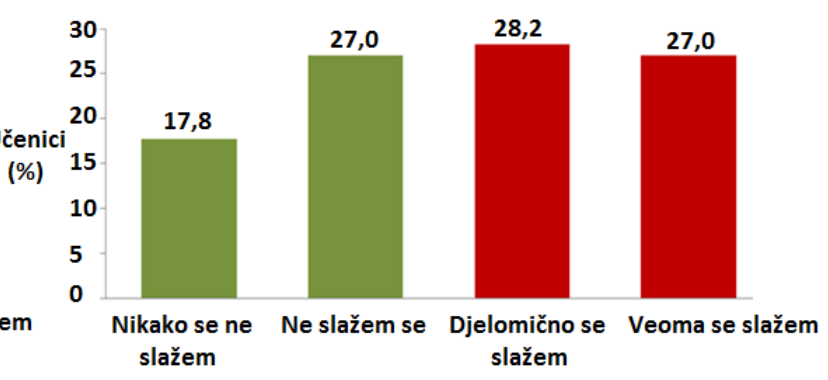

Moderan čovjek se razvio iz neandertalca.

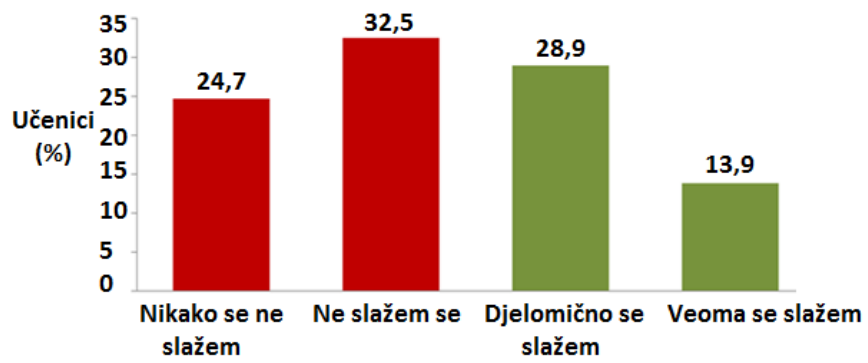

Više od polovice čovječjih gena je jednaka kao kod miša.

Slika 2 Najlošiji odgovori učenika o evoluciji čovjeka

Učenici osnovnih škola su postigli 30,34\% ukupne uspješnosti na ispitu znanja, stoga znanje osnovnoškolaca nije zadovoljavajuće. Na znanje uvelike utječe stav nastavnika do podučavanja evolucije čovjeka, razumijevanje razvoja čovjeka te postojeće miskoncepcije. Najčešće miskoncepcije su povezane s kreacionističkim vjerovanjima koja se protive konceptu evolucije. Takve miskoncepcije prisutne su i kod testiranih učenika. Učenici se zbog religijskog utjecaja slažu s tvrdnjom da su svi ljudi potomci biblijskog Adama i Eve te da biblijski prikaz najbolje opisuje razvoj čovjeka. To pokazuju i dosadašnja istraživanja (Brezovšek, 2016). 


\section{RASPRAVA}

Iz rezultata se može zaključiti da učenici slabo povezuju genetiku s evolucijom, nisu svjesni koliko je ljudskih gena jednako kao i kod miševa. Spomenute rezultate pokazala su i dosadašnja istraživanja (Brezovšček, 2016; Gešman, 2016; Mitevski, 2016), gdje učenici uopće ne povezuju genetiku s evolucijom. Unatoč slaganja učenika s tvrdnjom da su ljudi nastali u procesu evolucije, u procesu koji se konstantno događa, vrlo loši rezultati pokazali su se kod razvoja modernog čovjeka. Učenici smatraju da se moderan čovjek razvio iz neandertalca te da su se svi ljudi prvotno razvili iz čimpanzi. Brezovšček (2016), Gešman (2016) i Mitevski (2016) tvrde da takve rezultate pokazuju i slovenska istraživanja. Zbog nejasnoća u samom konceptu evolucije dolazi do određenih miskoncepcija te posljedično nerazumijevanja razvoja čovjeka. Nejasnoće se javljaju zbog nedostataka u otkrivanju pojedinačnih fosila, koje su još u otkrivanju. To učenicima predstavlja problem u razumijevanju $i$ prihvaćanju evolucijskog koncepta.

Za bolje razumijevanje i manji otpor učenika do evolucijskog koncepta predložena su moguća poboljšanja u podučavanju. Trebalo bi unaprijediti koncept podučavanja u smislu povezivanja evolucije čovjeka s drugim nastavnim predmetima. Predstaviti učenicima razvoj čovjeka pomoću praktičnih primjera koji se odnose na njihove živote. Kako bi približili znanstveni koncept evolucije, potrebno je koristiti što više fosila, evolucijskih dokaza koji jasno dokazuju ljudske pretke i njihove fizičke promjene, kao što je veličina mozga i oblik zuba čovjekolikih majmuna (Smith, 2010). To se može postići pomoću proučavanja, određivanja i uspoređivanja lubanja čovjekolikih majmuna s lubanjom modernog čovjeka (Price, 2012). Mafarth i suradnici (2004) predlažu predstavljanje učenicima tehniku 3D CT snimanja, gdje učenici mogu precizno analizirati lubanju Homo sapiensa i drugih bića, naglašavajući tako važnost fosila za objašnjenje ljudskog podrijetla. Uz mnoštvo ljudskih fosila će učenici lakše shvatiti da su u prošlosti postojali čovjekoliki majmuni čiji je progresivni razvoj tijela rezultirao svojstvima današnjih ljudi (Flammer, 2006).

Uz pomoć imunološkog sustava učenicima se može približiti razvoj organizama. Primjerom uzročnika ljudskih bolesti koji dobivaju otpornost na antibiotike, predstavljanjem laktozneintolerancije, evolucijske prilagodbe ljudskog tijela na nadmorske visine (Buss, 2012). Prepoznavanje i razumijevanje biološke raznolikosti pomoću filogenetskog stabla (Flammer, 2006), izradu geološke vremenske linije stvaranja svijeta i razvoja ljudi na Zemlji (Wuerth, 2004) te mnoge druge tehnike koje će učenicima pomoći u razumijevanju osobnog razvoja.

Učenicima treba osigurati izravno iskustvo s dokazima evolucije čovjeka te činjenicama s kojima će eliminirati postojeće miskoncepcije o vlastitom razvoju. To se može postići posjetom muzeja pronalaska neandertalaca U Hrvatskoj ili slovenskih izložbi o razvoju čovjekolikih majmuna pa sve do modernog čovjeka. Obrazovni konflikti između religije i znanosti postaju vrlo očiti, stoga moderno društvo može razviti nove obrazovne dizajne kod kojih nije nužno da vjera i evolucija budu u konfliktu (Jokić, 2013; Nelson, 2007; Ridley, 2004). Učenike treba upoznati s činjenicom da za kreacionistička uvjerenja nema empiričkih dokaza s kojima bi potvrdili religijsku teoriju. Na takve teorije mogu gledati kao jedan od mogućih pogleda na svijet, no ne kao znanstveni koncept (Buss, 2012). Svrha istraživanja bila je podizanje svijesti nastavnika o tome koliko je evolucija čovjeka važan koncept biologije u razumijevanju života. S ciljem unapređenja znanja hrvatskih i slovenskih učenika, obrazovnih ustanova, kurikuluma te nastavnika trebao bi se smanjiti utjecaj pogrešnih predodžbi o podrijetlu čovjeka. 


\section{ZAKLUČAK}

Prema provedenom istraživanju moguće je zaključiti:

$\checkmark$ na kraju osnovnoškolskog obrazovanja znanje učenika o evoluciji Homo sapiensa nije zadovoljavajuće

$\checkmark$ u Republici Hrvatskoj i Republici Sloveniji postoje razlike u razumijevanju koncepta evolucije čovjeka između učenika iste dobi

$\checkmark$ postoje značajne razlike među osnovnoškolcima i gimnazijalcima u razumijevanju koncepta evolucije čovjeka

hrvatski osnovnoškolci su pokazali više znanja od slovenskih osnovnoškolaca

$\checkmark$ slovenski gimnazijalci su na ispitu znanja pokazali bolje znanje od hrvatskih gimnazijalaca

$\checkmark$ u osnovnim školama bi se pristup nastavnika u podučavanju razvoja čovjeka trebao znatno poboljšati

ne postoje razlike između djevojaka i dječaka u znanju evolucije čovjeka

prisutne su miskoncepcije vezane uz koncept evolucije čovjeka i kod hrvatskih i kod slovenskih osnovnoškolaca te gimnazijalaca

za promjenu rezultata usvojenosti koncepta evolucije čovjeka kod učenika nužno je poboljšanje kurikuluma i u osnovnoj školi i u gimnaziji te jasnije definiranje ishoda vezanih uz evoluciju čovjeka.

\section{METODIČKI ZNAČAJ}

Rezultati istraživanja trebali bi utjecati na podizanje svijesti nastavnika o tome koliko je evolucija čovjeka važan koncept $u$ biologije te potaknuti promjene u promjeni paradigme poučavanja ovog koncepta. Pri tome je važno poznavati najčešće miskoncepcije učenika koje se vezano uz ovu temu pojavljuju kako bi ih se mogli spriječiti. Sve navedeno trebalo bi utjecati na promjene u poučavanju sa svrhom postizanja boljih rezultata učenika vezanih uz koncept evolucije čovjeka i kod hrvatskih i kod slovenskih učenika, a također i promjenama u kurikulumima s ciljem smanjenja stvaranja pogrešnih predodžbi o podrijetlu čovjeka.

\section{ZAHVALA}

Iskrena zahvala mentorici prof. dr. Jelki Strgar za profesionalno savjetovanje te profesoricama i profesorima u osnovnim i srednjim školama u kojima je provedeno istraživanje na posvećenom vremenu i želji za suradnjom.

\section{LITERATURA}

Alles D. L., Stevenson J. C. 2003. Teaching Human Evolution. The American BiologyTeacher, 65, 5: 333-339

Bajd B. 2010. Poučevanje evolucije človeka v slovenskih šolah. Opredelitevnaravoslovnihkompetenc. Maribor, Fakulteta za naravoslovjein matematiko: 208 str.

Bajd, B., Matyašek, J. 2009. Compromisonofsloveneandczechstudents' ideasabout human evolution. Schoolandhealth, 21: 265-273

Barnes E. M. 2014. ProfessorAttitudesandBeliefsaboutTeachingEvolution. MasterThesis. Arizona State University: 62 str. Brezovšček L. 2016. Znanje učencev 8. in 9. razreda osnovnih šol na Štajerskem oevoluciji človeka. Diplomsko delo. Ljubljana, Biotehniška fakulteta: 57 str.

Buss D. M. 2012. Evolucijska psihologija. Nova znanost o umu. Zagreb, Naklada Slap: 496 str.

Bybee R. W. 2004. Introduction-Evolutioninperspective: thescienceteachers'scompendium. Arlington, National Science TeachersAssociation: 98 str.

Farber P. 2003. TeachingEvolution\&The Nature Of Science. The American BiologyTeacher, 65, 5: 347-354

Flammer L. 2003. Teaching Human Evolution. Revisited. The American BiologyTeacher, 65, 8: 570

Flammer L. 2006. TheEvolutionSolution: TeachingEvolutionWithoutConflict. TheAmerican biologyteacher, 68, 3: 1-7

Gešman L. 2016. Znanje učencev 8. in 9. razreda osnovne šole na Dolenjskem o evoluciji človeka. Diplomsko delo. Ljubljana, Pedagoška fakulteta: 62 str.

Jokić, B. 2013. Science and religion in Croatian elementary education: pupils' attitudes and perspectives. Edition Science andsociety (34). Institute for Social Research, Zagreb. ISBN 978-953-6218-55-4

Mafart B., Guipert G., Lumley A. M., Subsol G. 2004. Three-dimensionalcomputerimagingofhominidfossils: a newstepin human evolutionstudies. CanadianAssociationofRadiologists Journal, 55, 4: 264-270 
Mitevski E. 2016. Znanje dijakov 1. in 2. letnika srednje šole v Ljubljani o evolucijičloveka. Diplomsko delo. Ljubljana, Pedagoška fakulteta: 67 str.

Mpeta M. 2013. The influence ofthebeliefsofteachersandlearners on theteachingandlearningofevolution. Doctoraldissertation. Pretoria. University of Pretoria: 454 str.

Nehm H. R., Schonfeld I. S. 2007. Doesincreasingbiologyteacherknowledgeofevolutionandthe nature ofsciencelead to greaterpreference for theteachingofevolutioninschools? Journal of Science TeacherEducation, 18: 699-723

Nelson C. E. 2007. Teachingevolutioneffectively: a centraldilemmaand alternativestrategies. McGill Journal ofEducation, 42, 2: 265-283

Pobiner B. L. 2012. Use human examples to teachevolution. The American BiologyTeacher, 74, 2: 71-72

Pobiner B. L. 2016. Accepting, Understanding, Teaching, andLearning (Human)Evolution: ObstaclesandOpportunities. YearbookofPsysicalAnthropology, 159, 231-274

Price R. M. 2012. How wegothere: evolutionarychangesinskullshapeinhumansandtheirancestors. The American BiologyTeacher, 74, 2: 106-110

Ridley M. 2004. Evolucija: Klasici i suvremene spoznaje. Zagreb, Naklada Jesenski i Turk: 477 str.

Smith C. 2010. Teachingevolutionin New Jerseypublichighschools: Examiningtheinfluence of personal beliefandreligiousbackground on teachingpractices. Doctoraldissertation. Minneapolis, Cappella University: 206 str.

Vican D., Litre I. M. 2006. Nastavni plan i program za osnovnu školu. Zagreb,Ministarstvo znanosti, obrazovanja i športa: 370 str.

Vičar M., Vilhar B., Zupančič G., GilčvertBernik D., Sojar A., Devetak B., Sobočan V.2008. Učninačrt. Program gimnazija. Biologija. Ljubljana, Ministrstvo RS za šolstvoin šport, Zavod RS za šolstvo: $82 \mathrm{str}$.

Vilhar B., Zupančič G., GilčvertBernik D., Vičar M., Zupan A., Sobočan V., Devetak B., Sojar A. 2011. Učninačrt. Program osnovna šola. Biologija. Ljubljana. Ministrstvo RS za šolstvoin šport, Zavod RS za šolstvo: 43 str.

Ministarstvo prosvjete i športa. 1995. Zagreb, Glasnik Ministarstva prosvjete i športa, 11: 11-14

Wuerth M. 2004. Resources for TeachingEvolution. The American BiologyTeacher, 66, 2: 109-113

Prilog 1 Anoniman ispit znanja o evoluciji čovjeka

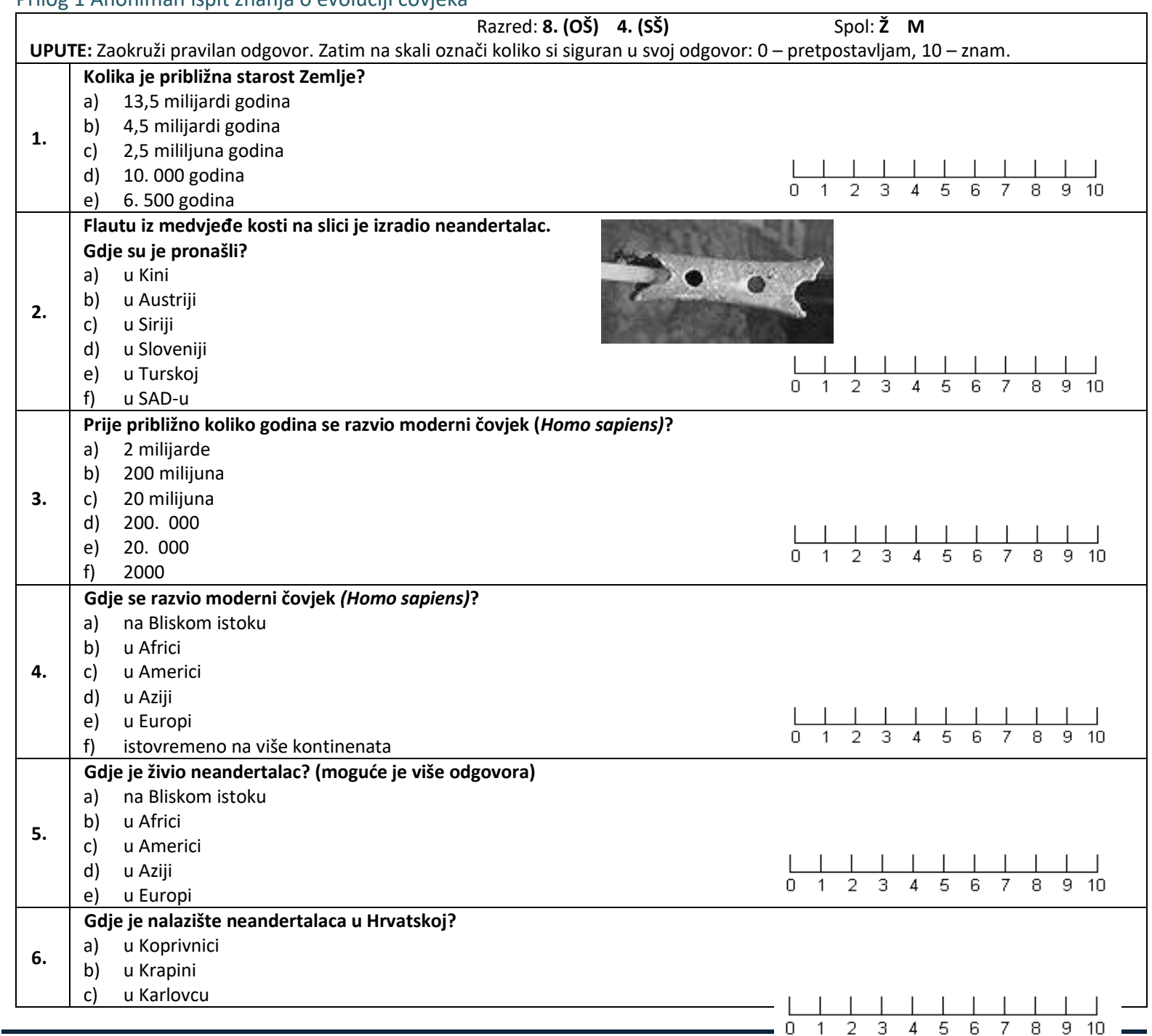

Broj 4, prosinac 2018. 
d) u Križevcima

e) u Kutini

UPUTE: Precizno pročitaj svaku tvrdnju i pored nje zaokruži u kojoj mjeri vrijedi za tebe. Ako se s pojedinačnom tvrdnjom nikako ne slažeš, zaokruži 1 . Ako se s tvrdnjom veoma slažeš, zaokruži 4.

1 - Nikako se ne slažem 2 - Ne slažem se 3 - Djelomično se slažem 4 - Veoma se slažem Koliko se slažeš sa sljedećim tvrdnjama?

7. Moderni čovjek (Homo sapiens) i neandertalac (Homo neanderthalensis) su istovremeno boravili na 7. Zemlji.

8. Čovjeku su gorile, orangutani i čimpanze najbliži srodnici po podrijetlu, s obzirom na posljednjeg zajedničkog pretka.

9. $\quad$ Život na Zemlji postoji već više od 3 milijarde godina.

10. $\quad$ Danas žive nove vrste živih bića koje u prošlosti nisu živjele.

11. Fosili pokazuju kako su se oblici života mijenjali kroz prošlost.

12. Ljudi su se razvili iz čimpanzi.

13. Više od polovice čovječjih gena je jednaka kao kod miša.

14. $\quad$ Nešto manje od polovice čovječjih gena je jednaka kao kod čimpanzi.

15. Teorija evolucije najbolje objašnjava kako se na Zemlji razvio čovjek.

\begin{tabular}{l|l}
16. & Ljudi i čimpanze su se razvili iz zajedničkog pretka. \\
\hline 17. & Prosječanvolumen mozga modernog čovjeka je
\end{tabular}

17. Prosječan volumen mozga modernog čovjeka je oko 1,5 litara.

18. $\quad$ Moderan čovjek je nastao procesom evolucije.

19. Moderan čovjek se razvio iz neandertalca.

20. Moderan čovjek je na današnjem prostoru Slovenije živio istovremeno kao i dinosauri.

21. Moderan čovjek je na današnjem prostoru Slovenije živio istovremeno kao i mamuti.

22. $\quad$ Nekad su na Zemlji živjele vrste živih bića koje su već izumrle.

23. $\quad$ Svi ljudi su potomci jednog muškarca i jedne žene - biblijskog Adama i Eve.

24. $\quad$ Posljednji zajednički predak čimpanze i čovjeka je živio prije 6-7 milijuna godina.

25. $\quad$ Čimpanze se mogu naučiti sporazumijevati govorom.

26. Danas su sve vrste čovjekolikih majmuna izumrle osim naše vrste, modernog čovjeka.

27. $\quad$ Australopiteci su već prije približno 4 milijuna godina hodali uspravno.

28. Neandertalac i moderan čovjek imaju 99,7 \% istih gena.

29. $\quad$ Današnji ljudi su se razvili iz prethodnih životinjskih vrsta.

30. Biblija najbolje objašnjava kako se na Zemlji razvio čovjek.

31. $\quad$ Zajednički predak ljudi i čimpanza još uvijek živi u Africi.

32. $\quad$ Evolucija (razvoj) modernog čovjeka još uvijek traje.

33. Anoniman test je bio razumljiv.

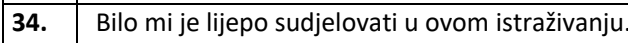

\begin{tabular}{|c|c|c|c|}
\hline 1 & 2 & 3 & 4 \\
\hline 1 & 2 & 3 & 4 \\
\hline 1 & 2 & 3 & 4 \\
\hline 1 & 2 & 3 & 4 \\
\hline 1 & 2 & 3 & 4 \\
\hline 1 & 2 & 3 & 4 \\
\hline 1 & 2 & 3 & 4 \\
\hline 1 & 2 & 3 & 4 \\
\hline 1 & 2 & 3 & 4 \\
\hline 1 & 2 & 3 & 4 \\
\hline 1 & 2 & 3 & 4 \\
\hline 1 & 2 & 3 & 4 \\
\hline 1 & 2 & 3 & 4 \\
\hline 1 & 2 & 3 & 4 \\
\hline 1 & 2 & 3 & 4 \\
\hline 1 & 2 & 3 & 4 \\
\hline 1 & 2 & 3 & 4 \\
\hline 1 & 2 & 3 & 4 \\
\hline 1 & 2 & 3 & 4 \\
\hline 1 & 2 & 3 & 4 \\
\hline 1 & 2 & 3 & 4 \\
\hline 1 & 2 & 3 & 4 \\
\hline 1 & 2 & 3 & 4 \\
\hline 1 & 2 & 3 & 4 \\
\hline 1 & 2 & 3 & 4 \\
\hline 1 & 2 & 3 & 4 \\
\hline 1 & 2 & 3 & 4 \\
\hline 1 & 2 & 3 & 4 \\
\hline
\end{tabular}

